our medical corporations, and all existing legislation, fail to shield us from the aggressions and competition of the unqualified practitioner, of every $k$ ind and degree, are equally facts of which no doubt can be entertained;" but these effects are perpetnated by regularly-educated physicians and surgeons meeting such persons in consultation, which is constantly done in this neighbourhoor. Nor can we wonder at it whilst they are the principal leaders in associations whose aroued object is " the maintenance of the hounur and respectability of the profession," and yet they admit as members persons who have never received a professional education, and a few years since were exercising their talents on the brute creation. How can the public place any dependence on their anxiety for medical reform?

The remedy proposed by Dr. Cowan would be violently opposed, although if it could be carried it would work much good; a simpler method would be to repeal the 26 th section of the 55 th Geo. III. (the Act for Regulating the Practice of Apothecaries throughout England and Wales), and to substitute for it a clause by which the penalties may be inflicted by the local magistrates. Under the present law the penalty for practising without a qualification must "be recovered by action or suit at law, in the name of the Master, Wardens, and Society of the Art and Mystery of A pothecaries of the City of London;" and unless they prosecute no one else can. Until the power thus vested be thrown open to the public, and the legal process made more simple and less expensive, there will always be cases which will escape prosecution; but if the Medical Association mean to do anything for the profession, instead of raising funds for the publication of Transactions in which a few of the members can figure as authors at the expense of the rest, they will apply themselves sedulously to the task, and this Act will be improved. In its present state it is a dead letter, the public having no power to put its provisions into execution, with one exception only, and of what avail is that? Few persons are aware that apothecaries not duly qualified cannot recover charges in a court of law, and of these a very small proportion would defend an action if the party had the temerity to bring one.

The Associations may act the part of medical censors, examining strictly into the qualification of all persons practising within the sphere of their operations, and collecting evidence to be submitted to the public, whilst great attention should be paid that none but properly qualified persons be admitted as members.

Had this been the case one, at least, must ere this, have retired from practice, as the mere taking up of the question by such a

No. 807. body would effectually restrain any man from going on who had no chance of suc. cess in a conrt of law. Let me hope, however, that having once commenced its discussion, this question may not be suffered to pass by, and that, with the able assistance of the public press, we may cheer the desponding, animate the talented, and compel the unwilling, unt ll we arrive at a "consummation so devoutly to be wished."

I am, Sir, your obedient servant, Grorgi SHEward,

Upton-upon-Serern,

Feb. 10, 1839.

\section{APPRENTICESHIP TO MEDICAL PRACTITIONERS.}

\section{To the Ealitor of THF LincrT.}

Sir :--In reply to a letter in Tin LAnceT of January 2oth, headed "Apprenticeship to Tllegal Medical Practitioners," written by Mr. Wm. Hempson Denham, of ivickham-market, as a friend and relative to the person alluded to, $\mathrm{I}$ beg to state that MTr. Denham is labouring ander a mistake when he asserts that the individual has not served an apprenticeship, and has obtained his certificates illegally. In contradiction to this unwarrantable assertion, $I$ can bring proof of the apprenticeship having been duly served, and that $I$ was myself instrumental to his entering the profession, for which he had long entertained a wish, but was fearful of his snccess, having been brought up in early life to other pursuits. I have great pleasure, bowever, in stating that $h$ is atfention to the duties of his profession at the hospitals was most assiduous, and gained him the esteem of his teachers, which remains to this day. Being myself a resident in London, I had every opportunity of witnessing his curemitted attention. I am not aware that any period has been legally fixed when an ap. prenticeship is to be begun; it is only neces. sary that one should be served, and where can the greater part of that time be better employed than at the hospital. The gentleman alluded to has done all that was required for his examination at the College of Surgeons and the Sociefy of Apothecaries. Mr. Denham's remarks are ungentlemanly and unfounded; but I am happy to say $\mathrm{m}$ : friend and relative stands too high in the estimation of the place and neighbourhood, in which he has resided for the last ten years (both is his professional and private character), to be injured by the word or the pen of such as Mr. Denham. I am, Sir, your obedient, humble servant,

\section{4, Wellington-street, Strand,} C. MuRIFi. Feb. 12, 1839.

N.B. Any farther insinuation relative to the above will be treated with the contempt it deserves. 